\title{
DEFINING KEY DESIGN PARAMETERS FOR SEPARATION CHAMBER OF FRACTIONING PNEUMATIC SEED SEPARATOR
}

Viktor Lazykyn, Aleksandr Burkov, Andrey Glushkov, Valentin Mokiyev

Federal Agricultural Research Center of the North-East named N.V. Rudnitsky, Russia ellestar@bk.ru,burkov.46@mail.ru

\begin{abstract}
The article studies the separation chamber of the pneumatic seed separator including the definition of its key design parameters and determining the best position of its rotary valve edge during wheat seed sorting. The experiment planning method helped us consider the effects the vertical $X\left(x_{1}\right)$ and horizontal $Y\left(x_{2}\right)$ positions of the rotary valve edge relative to the inlet edge in the separation chamber wall have on the distribution of grain material components in Fractions II and III. We established that it was possible to obtain Fraction II wheat, consistent with $\mathrm{RS}_{\mathrm{C}}$ commercial reproduction seed purity category with Fraction I seeds consistent with ES elite seed category and permissible loss levels. The required purity of Fraction II is achieved with the separation chamber minimum length of $L_{R . K}=0.55 \mathrm{~m}$ and the rotary valve length of $L_{K}=0.28 \mathrm{~m}$. The separation chamber partition edge with the rotary valve is located $0.40 \mathrm{~m}$ away from the inlet edge of the front wall and $0.30 \mathrm{~m}$ below its level. The highest purity of Fraction II $P_{\mathrm{II}}=98.4 \%$ is achieved when the rotary valve edge is set in position $x_{1}=-1\left(X_{K}=0.25 \mathrm{~m}\right)$ and $x_{2}=-1\left(Y_{K}=-0.10 \mathrm{~m}\right)$. The highest purity of Fraction III with permissible levels of sound seed loss (Fraction IV) is achieved when the outlet edge in the separation chamber wall is positioned at the same level as the inlet edge (the duster inlet height $H_{V}=0.21 \mathrm{~m}$ ). The results of the research can be used in the development of pneumatic systems for seed-purifying machines.
\end{abstract}

Keywords: seeds, fractioning, pneumatic separator, separation chamber, rotary valve.

\section{Introduction}

The use of fractioning technology at all of the purifying stages involving the sorting of seeds depending on their aerodynamic properties, sizes, density, etc. is a key area of improvement in the postharvest treatment of grain. Studies aimed at studying the process of grain fractionation are conducted both in the Russian Federation and abroad. In [1-4], the issues of improving the efficiency of grain and seed cleaning by fractionation on sieves and by the air flow in vertical, inclined and horizontal pneumatic separation channels (PSK) and chambers are considered. Specific technical solutions and their effectiveness are given. The aim of the work [5] was to create and optimize the design of a mobile separator for efficient cleaning and fractionation of wheat grains with the maximum possible preservation of their physical, chemical, structural and mechanical properties. In [6], we studied the physical and technological properties of five wheat varieties depending on humidity, which allows us to optimize the processes of post-harvest grain processing. The authors of the work [7] showed that the most effective method of sorting seeds by specific gravity is vibropneumatic sorting in a fluidized bed. Based on the conducted research, the design and technological scheme of a direct-flow vibropneumatic separator is scientifically justified and practically implemented. In [8], the process of separation of soybean husk in an inclined air flow is considered. It is shown that the increased humidity of the mixture leads to a significant decrease in the efficiency of material separation. The most important influence on the quality of cleaning is the correct choice of the air flow rate.

The second and final stages of seed treatment widely employ pneumatic grain separators (SAD-10, PSM-5, -10, -25, -40, SMVO-10B, PS-15, A1-BDK-2.5, A1-BD3-6, -12, SP-5) [9; 10; 11]. Separators of the SAD-10 type divide the cleaned material into 5...10 fractions and for this reason have an increased length of the separation chamber, which leads to a large overall size of the machine. Separators such as PSM and SMVO-10B qualitatively divide the material into three fractions, but have high energy consumption. The other separators marked separate the material into only two fractions. For the treatment of seeds of cereals, herbs, vegetables, flowers and medicinal plants, a universal pneumatic separator SP-2U with a double vertical PSK and a support grid is used [11]. The main drawback of this separator is that it cannot sort the seeds by fractions according to purity categories of ES and $\mathrm{RS}_{\mathrm{C}}$ or above in one go, which results in the increased treatment costs. The FSBSI FARC of the North-East developed the SP-2F fractioning pneumatic separator that can sort the material into four fractions in one go: first- and second-rate seeds consistent with $\mathrm{ES}$ and $\mathrm{RS}_{\mathrm{C}}$ categories, forage grain fraction, and the unused wastes [12]. In this separator, the influence of the design parameters of the separation chamber on the quality of the technological process has not been sufficiently studied. 


\section{Materials and Methods}

The SP-2F separator (Figure 1) features a double aspiration channel (PSK) 3 with a support grid 1 and solid partition 4 that form the separation 5 and settling 15 chambers consecutively, as well as a louver reflux inertia duster 14 located in the settling and the separation chambers, and the cross-flow suction fan with a throttle valve 13. The separation chamber 5 has increased length.

The material fractioning occurs as follows. The input device 2 feeds the material into PSK 3 and onto the support grid 1, where it is blown-through with the air taken by the cross-flow fan from the atmosphere. In the first channel segment light impurities are ejected that go to the upper part of the separation chamber 5 through the branch 8 . In the second channel segment the material is treated at a higher airflow speed. The remaining light impurities, as well as feeble, crushed, and small grains are ejected and taken into the middle section of the separation chamber 5 through the branch 8 . The material purified in PSK is first-rate seeds. The lightest impurities move in the upper layers of the airflow in the separation chamber 5 and enter the duster inlet 9 . In the middle part of the chamber, heavier particles settle in sections I and II, while lighter particles are ejected through the duster 14. Second-rate seeds mostly settle in the first section, while feeble and crushed grains, as well as weed seeds and some of the light impurities comprising the forage fraction, settle in the second section. The quality of the seed material fractioning heavily depends on the design parameters of the separation chamber 5 and the position of the rotary valve edge 16 set in partition 17 . Therefore, the aim of this research is to determine the best design parameters of the separation chamber that would provide the purity of Fraction I seeds of at least $99.0 \%$ and $97.0 \%$ for Fraction II seeds, consistent with the ES and RS $\mathrm{C}$ categories (GOST R 52325-2005) with the permissible seed loss level of $10 \%$ [10].

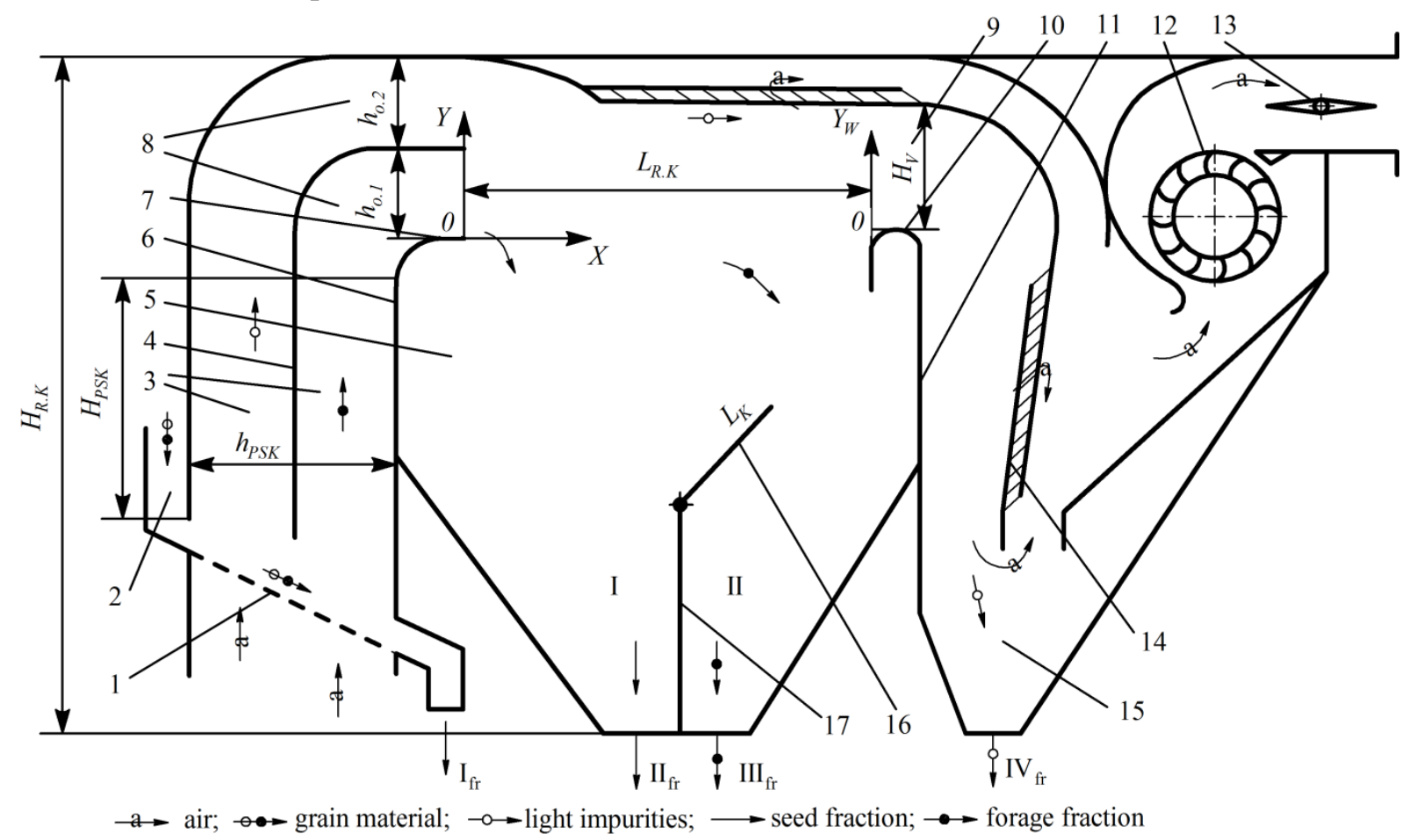

Fig. 1. Process flow chart for the SP-2F separator: 1 - support grid; 2 -input device;

3 -double PSK; 4 - solid partition; 5-separation chamber; 6, 11 - front and back walls of the separation chamber; 7, 10 - input and output edges of the separation chamber walls; 8 - PSK branch; 9 - duster inlet; 12 - cross-flow suction fan; 13 - throttle valve; 14 - duster; 15 - settling chamber;

16 - rotary valve; 17 - separation chamber partition; $\mathrm{I}_{\mathrm{fr}}, \mathrm{II}_{\mathrm{fr}}, \mathrm{III}_{\mathrm{fr}}, \mathrm{IV}_{\mathrm{fr}}-$ purified material fractions

The study of the separation chamber included determining the best position of the rotary valve edge in the separation chamber when sorting wheat seeds, optimizing the length of the $L_{R . K}$ of the chamber 5 and the vertical position $Y_{W}$ of the output edge 10 of the back wall 11 of the separation chamber. The treated material comprised $95 \%$ spring wheat seeds, $3 \%$ feeble winter rye seeds, and $2 \%$ light impurities (wooden sawdust) with hovering velocities of $8.3 \ldots 11.6 \mathrm{~m} \cdot \mathrm{s}^{-1}, 5.6 \ldots 9.9 \mathrm{~m} \cdot \mathrm{s}^{-1}$, and $0.5 \ldots 5.0 \mathrm{~m} \cdot \mathrm{s}^{-1}$, respectively. To study the effects of the rotary valve edge position on the distribution of the treated 
material components in the separation chamber with the permissible grain loss levels, a second-order full-scale experiment plan was implemented for two factors: the horizontal $X_{K}\left(x_{1}\right)$ and vertical $Y_{K}\left(x_{2}\right)$ position of the rotary valve edge relative to the inlet edge in the separation chamber wall $[14 ; 15]$. The edge of the rotary valve was set in three horizontal positions $X$ relative to the inlet edge of the separation chamber wall: $0.25 ; 0.35 ; 0.45 \mathrm{~m}$, and in vertical positions $Y:-0.10 ;-0.05 ; 0 \mathrm{~m}$, respectively. The factors and their variance levels were selected based on the results of single-factor experiments. The purity $P_{\text {II }}$ of the Fraction II seeds was used as the assessment criterion for the separation process. The study was carried out with the following constant separation chamber parameters: separation chamber length $L_{R . K}$ - $0.7 \mathrm{~m}$; separation chamber height $H_{R . K}-1.7 \mathrm{~m}$; PSK height $H_{P S K}-0.4 \mathrm{~m}$; PSK depth $h_{P S K}-0.3 \mathrm{~m}$; branch depths $h_{O .1}$ and $h_{O .2}-0.22$ and $0.08 \mathrm{~m}$, respectively; duster inlet depth $H_{V}-0.21 \mathrm{~m}$. The width of the flow channel in all of the pneumatic separator elements is $0.30 \mathrm{~m}$. The cross-flow suction fan is made according to the patent RU No.2204057 [16], has a spiral body with a louvered adjacent wall of the discharge pipe, a 24-blade wheel with a diameter of $0.4 \mathrm{~m}$, a length of $0.3 \mathrm{~m}$. At a speed of $800 \mathrm{~min}^{-}$ ${ }^{1}$, the fan provides a speed of $v_{W}$ of air flow in PSK up to $12.0 \mathrm{~m} \cdot \mathrm{s}^{-1}$. The speed $v_{W}$ in PSK was set by the throttle valve 13 according to the permissible losses of grain to waste. During the experiments, the velocity $v_{W}$ in the first part of the channel was $8.5 \mathrm{~m} \cdot \mathrm{s}^{-1}$, in the second part $-11.0 \mathrm{~m} \cdot \mathrm{s}^{-1}$. The experiments were carried out in 4 -fold repetition.

After studying the effects of the rotary valve edge position on the distribution of the grain material in Fractions II and III, we determined the best length $L_{R . K}$ and vertical position $Y_{W}$ of the outlet edge 5 of the back wall 6 of the separation chamber. The tests were carried out using the best rotary valve edge position for wheat grain purifying. The experiment conditions remained the same as in the previous test. Separation chamber length $L_{R . K}$ was set at three levels: $0.55 ; 0.625 ; 0.70 \mathrm{~m}$, and the vertical position $Y_{W}$ of the back wall outlet edge of the separation chamber was set at $-0.10 ;-0.05 ; 0 \mathrm{~m}$, respectively. The goal of this research is to determine the minimum length of the separation chamber and the position of the wall outlet edge determining the height $H_{V}$ of the duster outlet that would provide the minimum weight of the light impurities $\left(m_{O}\right)$ in Fraction III as compared to their content (percentage) in the original material, while the sound grain losses $a$ (Fraction IV) will not exceed the permissible level $(10 \%)$. Experiment results were processed on a computer using the STATGRAPHICS + software package for statistical data processing. We assessed the adequacy of regression analysis models using the Fisher's criterion (F) with the probability of $p=0.95$, and we assessed the significance of regression coefficients using the Student's t-test.

\section{Results and discussion}

After the implementation of the experiment plan and the processing of the experimental data, we obtained an adequate second-order regression model for purity $P_{\mathrm{II}}$ of Fraction II wheat (\%):

$$
Y_{P \mathrm{II}}=95.57-1.20 x_{1}-0.85 x_{2}+0.80 x_{1}{ }^{2} \text {. }
$$

The analysis of the regression model (1) using the 2-dimension cross-section method (Figure 2) showed the following. The highest seed purity value $P_{\mathrm{II}}=98.4 \%$ was obtained at $x_{1}=-1\left(X_{K}=0.25 \mathrm{~m}\right)$ and $x_{2}=-1\left(Y_{K}=-0.10 \mathrm{~m}\right)$ due to the shifting of the rotary valve edge to the area with the smallest content of grain impurities. In this case, second-rate seeds contain grain impurities at a rate of $187 \mathrm{pcs} \cdot \mathrm{kg}^{-1}$, which corresponds to the requirements of GOST R 52325-2005 (not more than $200 \mathrm{pcs}^{\circ} \mathrm{kg}^{-1}$ for $\mathrm{RS}_{\mathrm{C}}$ category seeds). Sound grain losses $a$ amount to $5.4 \%$, and the fraction yield is as follows: I $-74.4 \%$, II $-4.5 \%$, III $-15.7 \%$ of the original material, and the fraction purity $P$ is: I $-100 \%$, II $-98.4 \%$, III $91.9 \%$. Thus, the conducted separation chamber tests for the fractioning pneumatic seed separator confirmed that it is possible to obtain Fraction II wheat corresponding to purity category $\mathrm{RS}_{\mathrm{C}}$ with $100 \%$ pure Fraction I seeds.

When studying the best length $L_{R . K}$ and vertical position $Y_{W}$ of the outlet edge 5 (Figure 1) in the back wall 6 of the separation chamber during the plan implementation and experimental data processing, we obtained adequate second-order regression models for sound grain losses $a(\%)$ and the light impurity proportion $m_{O}(\%)$ in Fraction III:

$$
\begin{aligned}
Y_{a} & =4.52-1.23 x_{1}-2.10 x_{2}+0.70 x_{1} \cdot x_{2}, \\
Y_{m o} & =6.90+2.48 x_{1}+4.43 x_{2}+0.67 x_{1} \cdot x_{2} .
\end{aligned}
$$




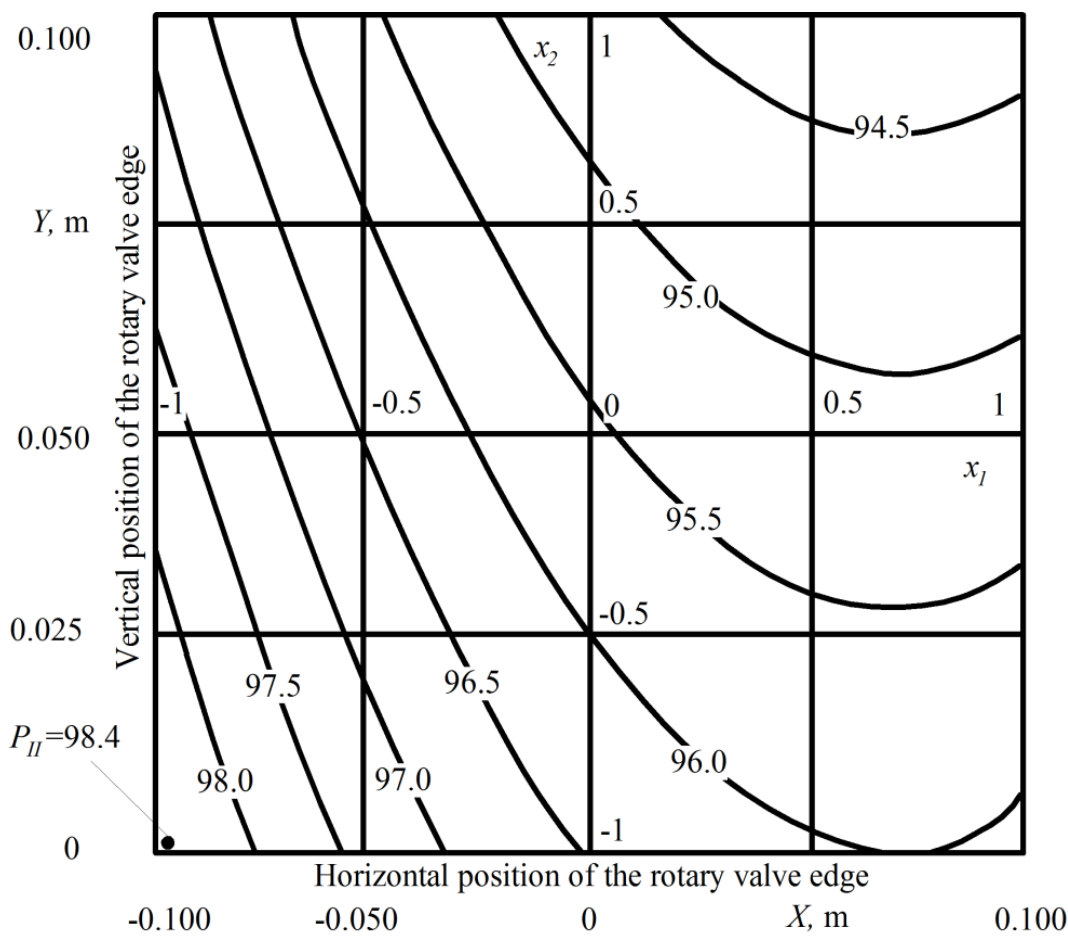

Fig. 2. 2-dimension cross-section of the response surface characterizing the effects of the rotary valve edge position (factors $x_{1}$ and $x_{2}$ ) on the purity $P_{\text {II }}$ of Fraction II material in the separation chamber $(\%)$

The analysis of the regression models ( 2 and 3 ) using the 2-dimension cross-section method (Figure $3)$ showed the following. The minimum loss value $a=1.89 \%$ is obtained, when $x_{1}=+1\left(L_{R . K}=0.7 \mathrm{~m}\right)$ and $x_{2}=+1\left(Y_{W}=0 \mathrm{~m}\right)$, and the minimum light impurity proportion $m_{O}=0.66 \%$ obtained with $x_{1}=-1$ $\left(L_{R . K}=0.55 \mathrm{~m}\right)$ and $x_{2}=-1\left(Y_{W}=-0.10 \mathrm{~m}\right)$.

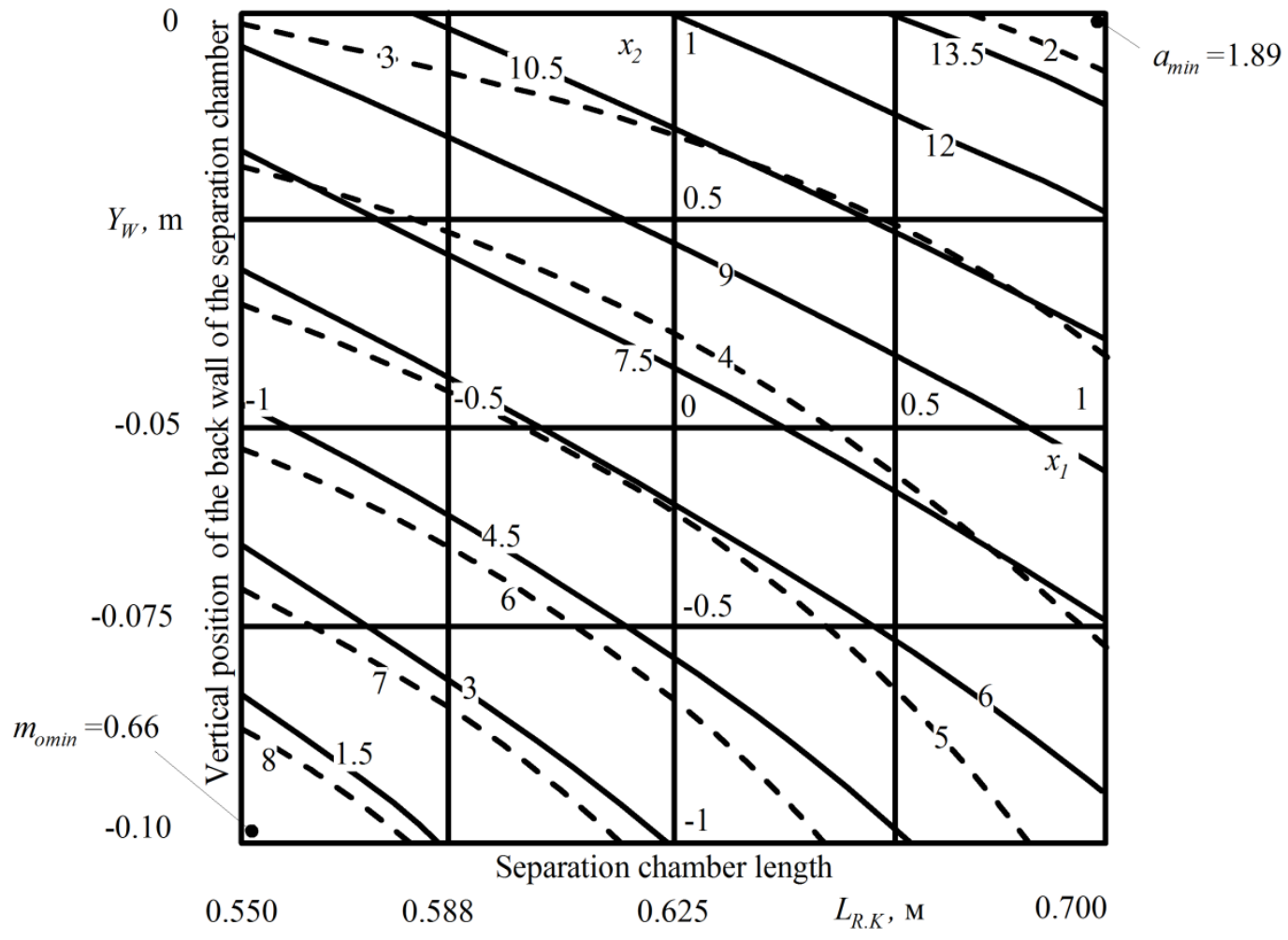

Fig. 3. 2-dimensional cross-sections of the response surfaces characterizing the effects of factors

$L_{R . K}$ and $Y_{W}$ on the sound grain losses $a(--)^{-}(\%)$ and the proportion of light impurities $m_{o}(\longrightarrow)$ in Fraction III (\%) 
In this case, the decrease of the separation chamber length $L_{R . K}$ leads to the increased grain losses $a$ and the reduction of light impurity proportion $m_{O}$ in Fraction III, because the treated material remains in it for a shorter period of time. Lowering the back wall outlet edge below zero (increasing $H_{V}$ ) also results in increased grain loss $a$ and decreased light impurity proportion $m_{O}$ in Fraction III.

The sound grain losses $a$ are within the permissible values across the entire range of the factors examined. Therefore, we use the minimum separation chamber length $L_{R . K}$ of $0.55 \mathrm{~m}$. Since the first of the two fractioning assessment criteria (sound grain loss $a$ ) is more important, we set the $Y_{W}$ factor at the maximum. The back wall outlet edge will be located at the same level as the front wall inlet edge, and the inlet height $H_{V}$ will be $0.21 \mathrm{~m}$. These separation chamber parameters will allow reducing the length of the pneumatic separator by $0.15 \mathrm{~m}$ and ensure that the sound grain losses $a$ are below $3.0 \%$ with the proportion of light impurities $m_{O}$ in Fraction III of 9.5\%.

The results of the separation chamber tests to determine the effects of the design parameters and rotary valve edge position on the quality of Fractions II and III wheat purification with permissible loss levels were used to determine the length $L_{K}$ of the rotary valve and the installation point for the partition edge $A$ (Figure 4).

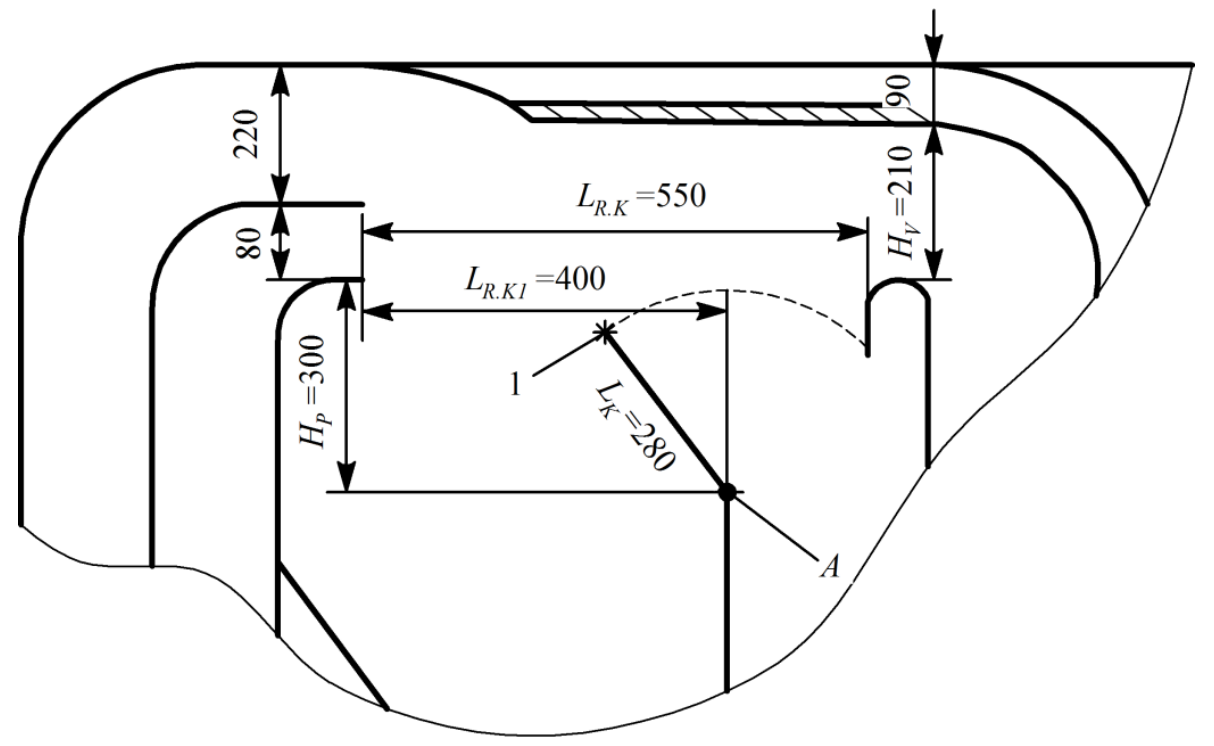

Fig. 4. Rotary valve and partition installation layout for the separation chamber: 1 - best position of the rotary valve edge for summer wheat purification; - - - - rotary valve edge motion path

The separation chamber partition is located vertically at a distance of $L_{R . K 1}=0.40 \mathrm{~m}$ from its inlet edge and $H_{P}=0.30 \mathrm{~m}$ below the chamber inlet edge. The length of the rotary valve is $L_{K}=0.28 \mathrm{~m}$.

\section{Conclusions}

The summer wheat purification tests carried out on the separation chambers showed that it is possible to obtain Fraction II seeds that would comply with purity category $\mathrm{RS}_{\mathrm{C}}$ for commercial reproduction seeds with Fraction I seeds complying with purity category ES at least and the permissible levels of loss. The required purity of Fraction II seeds is obtained at the minimum chamber length $L_{P . K}$ of $0.55 \mathrm{~m}$ and the rotary valve length $L_{K}$ of $0.28 \mathrm{~m}$. The valve shall be installed on the partition edge, $0.40 \mathrm{~m}$ away from the front wall inlet edge and $0.30 \mathrm{~m}$ below it. In this case, the highest purity of Fraction III with permissible sound seed loss (Fraction IV) levels is obtained when the outlet edge of the separation chamber wall is at the same level as the inlet edge (the duster inlet height $H_{V}=0.21 \mathrm{~m}$ ).

\section{References}

[1] Оробинский В.И. Фракционирование зерна. Совершенствование послеуборочной обработки семян (Grainfractionation. Improvement of postharvest seed treatment). Germany, Saarbrucken: LAP Lambert Academic Publishing, 2012, 380 p. (In Russian). 
[2] Ермольев Ю.И., Шелков М.В., Бутовченко А.В. Современные технологии и технические средства для очистки семенного зерна (Modern technologies and technical means for cleaning seed grain).// Agricultural machinery and technology, vol. 3, 2012, pp. 29-32. (In Russian).

[3] Бурков А.И., Глушков А.Л., Лазыкин В.А.Разработка зерноочистительных машин, работающих по фракционной технологии (Development of grain-cleaning machines working on fractional technology). Perm Agrarian Journal, vol. 23, 2018, pp. 12-19. (In Russian).

[4] Shepelev S.D. Studying the Trajectory of Moving Particles in the Air-Screw Separator. IOP Conf. Series: Materials Science and Engineering 582, 2019, pp. 1-5. DOI: 10.1088/1757899X/582/1/012031.

[5] Barakayev N.R., Rajabov A.N., Kurbanov M.T., Kuzibekov S.K. Improvement of the design of mobile equipment for post-harvest processing of agricultural crops. Journal of critical reviews, vol. 7, 2020, pp. 306-309. DOI: 10.31838/jcr.07.14.54.

[6] Kalkan F., Kara M. Handling, frictional and technological properties of wheat as affected by moisture content and cultivar. Powder technology journal vol. 213, 2011, pp. 116-122. DOI: 10.1016/j.powtec.2011.07.015.

[7] Shilo I., Pozdniakov V., Zelenko S. RESEARCH OF PERFORMANCE OF VIBRO-PNEUMATIC SEPARATOR. Mechanical and electrical engineering vol. 26, 2020, pp. 163-172. DOI: 10.24263/2225-2924-2020-26-6-18.

[8] Panasiewicz M., Sobczaka P., Mazura J., Zawiślaka K., Andrejko D.The technique and analysis of the process of separation and cleaning grain materials. Journal of Food Engineering, vol. 109(3), 2012, pp. 603-608. DOI: 10.1016/j.jfoodeng.2011.10.010.

[9] Еров Ю.В., Нуруллин Э.Г., Каримов Х.З., Салахиев Д.З. Инновации в послеуборочной обработке зерна и семян (Innovations in post-harvest grain and seed processing). Kazan': Slovo: Springer, 2009. 104 p. (In Russian).

[10]Карманов Д.К., Карманова Г.К. Обзор существующих технологических схем пневмосепараторов (Overview of existing technological schemes of pneumatic separators). AgroSnabForum, vol. 7, 2015, pp. 26-27. (In Russian).

[11]Бурков А.И., Баталова Г.А., Глушков А.Л., Лазыкин В.А. Подготовка высококачественных семян с использованием пневмосепараторов (Preparation of high-quality seeds using pneumatic separators). Agricultural science Euro-North-East, vol. 2, 2017, pp. 72-76. (In Russian).

[12] Patent RU №2654985. Фракционный пневмосепаратор (Fractional pneumoseparation). Авторы: Бурков А.И., Глушков А.Л., Лазыкин В.А., 2018.

[13] Технологические требования к новым техническим средствам в растениеводстве (Technological requirements for new technical means in crop production). Moscow: Rosinformagrotekh, 2008. 60 p. (In Russian).

[14] Michael D.Casler. Fundamentals of Experimental Design: Guidelines for Designing Successful Experiments Agronomy Journal, vol. 107, 2015, pp. 692-705. DOI: 10.2134/agronj2013.0114.

[15] Gaeton, C., and X. Guyon. Spatial statistics and modeling. New York: Springer, 2010. 308 p.

[16] Patent RU №2204057. Диаметральный вентилятор (Cross-flow suction fan). Авторы: Бурков А.И., Рощин О.П., Исупов В.И., Ефремов Д.Ф., Кутюков А.М.,2013. (In Russian) 